\title{
THE COMPLEXITIES OF THE THREE-DIMENSIONAL SHAPE OF INDIVIDUAL CRYSTALS IN GLACIER ICE
}

\author{
By George P. Rigsby \\ U.S. Army Cold Regions Research and Engineering Laboratory, Hanover, \\ New Hampshire, 03755, U.S.A.)
}

\begin{abstract}
Arstract. A block of ice from Blue Glacier, Washington, was successively sectioned at close intervals as a means of determining exact crystal shape in three dimensions. Two crystals occupying over 20 per cent of the entire sample are used as examples, and their volumes calculated. These crystals were found to be much larger and more complex in shape than expected from thin-section examination alone. The surface-tovolume ratio was calculated using a simple relationship between the length of lines in a grid crossing the crystal and grid-line intercepts with the crystal boundary. From this ratio the surface are $x$ of each crystal was calculated.

A measurement of irregularity or jaggedness is introduced in order to compare crystals of different size with one another. This is necessary because surface-to-volume ratio of a body of the same shape decreases as the size increases.
\end{abstract}

RÉsumé. Les complexités de la forme tri-dimensionnelle de cristaux individuels de glace de glacier. Un bloc de glace de Blue Glacier, Washington, a été coupé successivement à petits intervalles comme moyen de déterminer la forme tri-dimensionnelle exacte des cristaux. Deux cristaux, occupant plus que $20 \%$ de tout l'échantillon, ont été utilisés comme exemples et leur volume a été calculé. Ces cristaux furent plus grands et leur forme plus compliquée que la seule investigation des coupes minces le laissait prévoir. Le rapport surface-volume a été calculé en utilisant une relation simple entre la longueur de lines d'une grille posée sur le cristal et les intersections de cette grille avec le contour du cristal. La surface de chaque cristal a été calculée à partir de ce rapport.

Une mesure de l'irrégularité ou de boursoufflure est introduite pour comparer les cristaux de différentes tailles les uns avec les autres. Cela est nécessaire parce que le rapport surface-volume d'une corps de même forme décroît lorque la taille diminue.

Zusammenfassung. Die Kompliziertheiten der dreidimensionalen Form einzelner Kristalle in Gletschereis. Von einem Eisblock des Blue Glacier, Washington, wurden dicht benachbarte Schnitte hergestellt, um die dreidimensionale Kristallgestalt exakt zu bestimmen. Zwei Kristalle, die $20 \%$ der Gesamtprobe ausmachten, werden als Beispiele herangezogen; ihr Volumen wird berechnet. Diese Kristalle erwiesen sich als viel grösser und komplizierter als man durch Untersuchungen von Dünnschliffen allein erwarten würde. Das Verhältnis von Oberfläche zu Volumen wurde durch Verwendung einer einfachen Beziehung zwischen der Länge von Gitterlinien, die den Kristall kreuzen, und den Schnittpunkten von Gitterlinien mit dem Kristallrand, bestimmt. Aus diesem Verhältnis wurde die Oberfläche jedes Kristalls berechnet.

Ein Mass für die Unregelmässigkeit oder Zähnung wurde eingeführt, um Kristalle unterschiedlicher Grösse miteinander vergleichen zu können. Dies ist notwendig, weil das Verhältnis der Oberfläche zum Volumen eines gleichgestalteten Körpers mit zunehmender Grösse abnimmt.

\section{INTRODUCTION}

In many scientific fields, cellular structures or crystal aggregates are observed only in twodimensional section. The relationships in three dimensions must be inferred. Examples include the petrologist's thin section, the polished section of the opaque minerals and the biologist's microtome slice. Henri Bader (personal communication, February r 962) observed that little is known about shapes of the ice crystals in glacier ice. The objective of the present study, motivated by this observation, was to trace the crystals in three dimensions and to test statistically whether three-dimensional shape parameters could be obtained from random sectioning.

Most cores from glaciers appear the same in thin sections of different orientation. Rarely is there any observable preferred orientation of elongated crystals, although the orientations of the optic axes in glacier ice are usually highly anisotropic.

A sample of fairly coarse-grained glacier ice, with crystals from about 3 to $8 \mathrm{~cm}$ across was desired. If the grain-size were too small, determination of crystal boundaries in the third dimension would be difficult, and if too large, handling too much ice to obtain sufficient data would be required. The sample chosen proved excellent for the techniques finally used.

The ice sample was collected from Blue Glacier, Olympic Mountains, Washington, during the summer of 1962 . It came from a location only a few hundred yards above the part 
of the terminus where the slope increases drastically, and slightly east of the center on the transverse line. The foliation dipped about $40^{\circ}$ up-glacier. Only a few inches of the surface ice were removed before chopping out the block. Although the location was in the ablation zone, this part of the glacier is free of debris and undoubtedly the ice was active. The laboratory work was done at the Cold Regions Research and Engineering Laboratory, Hanover, New Hampshire, which provided excellent facilities and an assistant.

\section{Description of Sample and Laboratory Method of Study}

The trimmed block of glacier ice measured about $32 \times 21 \times 23 \mathrm{~cm}$. To the writer's knowledge, thin sections from such large samples had not previously been made, especially as thin as required for the accurate orientation of the optic axes. It was initially felt that the crystals might be traced by etching the boundaries and making successive pencil rubbings on faces spaced every 3 or $4 \mathrm{~mm}$ through the block. This method gives no crystal-orientation data and experiments with artificial ice showed that the boundaries of the individual crystals could not be followed from one rubbing to another. Etching and photographing also proved unsuccessful. Bright spots from the lights obscured some of the boundaries and, of course, no crystal-orientation data were obtained.

Therefore, it appeared that successive thin sectioning with orientation determination of each crystal by a universal stage was the only sure way to follow the crystals through the block, even though handling large thin sections without breaking or shattering was difficult.

A technique was developed in which a plate of window glass was frozen to the smoothed upper surface of the ice. Thus supported, the ice section could be cut as thin as $\mathrm{I} .5 \mathrm{~mm}$ with a large band saw. After sawing, the section was further thinned with coarse sandpaper glued to a flat board. After thinning to about $\mathrm{I} \mathrm{mm}$, another glass was frozen to the exposed side giving a good surface for photographing between crossed polaroid sheets. This was done on $4 \times 5 \mathrm{~cm}$ polaroid film ( $\mathrm{P} / \mathrm{N}$ type) to produce immediately a negative and a positive. Photographs of two orientations, rotated about $40-45^{\circ}$ were required in order to see most of the boundaries (Figs. I-6). When obscure boundaries were encountered, they were traced on the photographs from the universal stage during the axis-orientation process.

Enlarged photographs, printed with a matte surface, were used to number the grains for recording the orientation and to trace the boundaries. From these photographs the final tracings were made on plastic film which could be xeroxed for measuring, and for coloring or other means of identification of individual crystals. Very few of the photographs were exactly to scale, but corrections in numbers of intercepts, length of lines and areas were made. For location reference, the left and bottom margins on all section tracings are in register.

This procedure resulted in a minimum of about $3.5 \mathrm{~mm}$ between successive cuts. Irregularities in sawing caused the distances between successive thin sections to vary between 3.2 and $7.1 \mathrm{~mm}$. The thickness for each section given in Tables I and II in column $t$ is the value measuring from half-way between each section, as these values seemed best to use for volume calculations.

After photographing the large sections, they had to be cut into small units $(4 \times 4$ in; I $0.2 \times 10.2 \mathrm{~cm})$ to be used on the universal stage. The top glass cover plate was removed by applying just enough heat uniformly over the surface of the glass to loosen it. With the section still frozen to the bottom glass, $10.2 \times 10.2 \mathrm{~cm}$ squares were marked and cut to the glass with a hand saw. After preparing again with sandpaper, a glass cover plate cut to the same size was frozen to the upper surface of each square before removal from the large bottom plate. The final preparation of the sections was made on the microtome. The ice thickness was between 0.10 and $0.15 \mathrm{~mm}$ when the final bottom glass $(12.7 \times \mathrm{II} .4 \mathrm{~cm})$ was frozen to the section. A bead of ice was then frozen to the edge of the smaller or top glass to prevent sublimation of the thin section. 


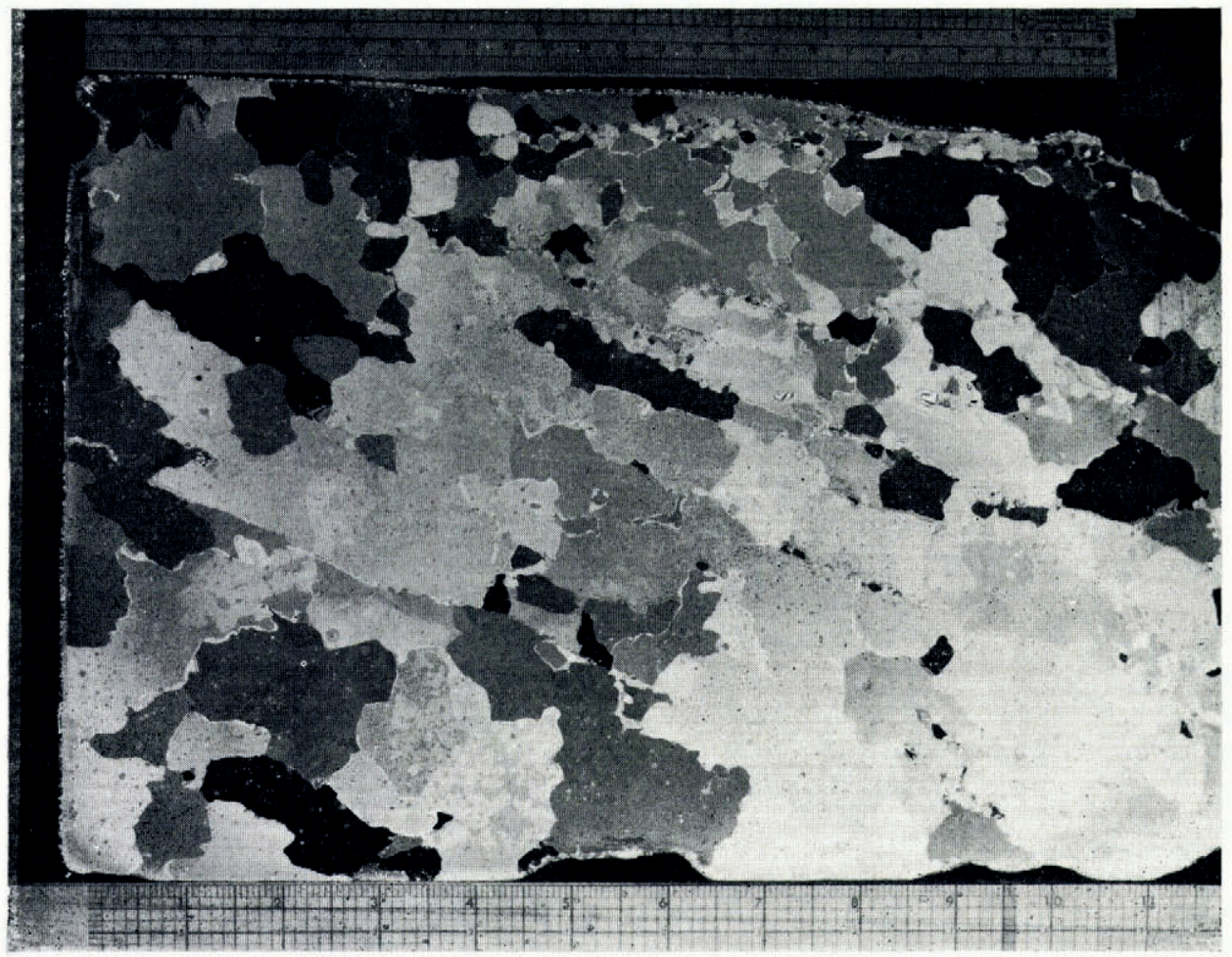

Fig. I. Section 4; polarized light

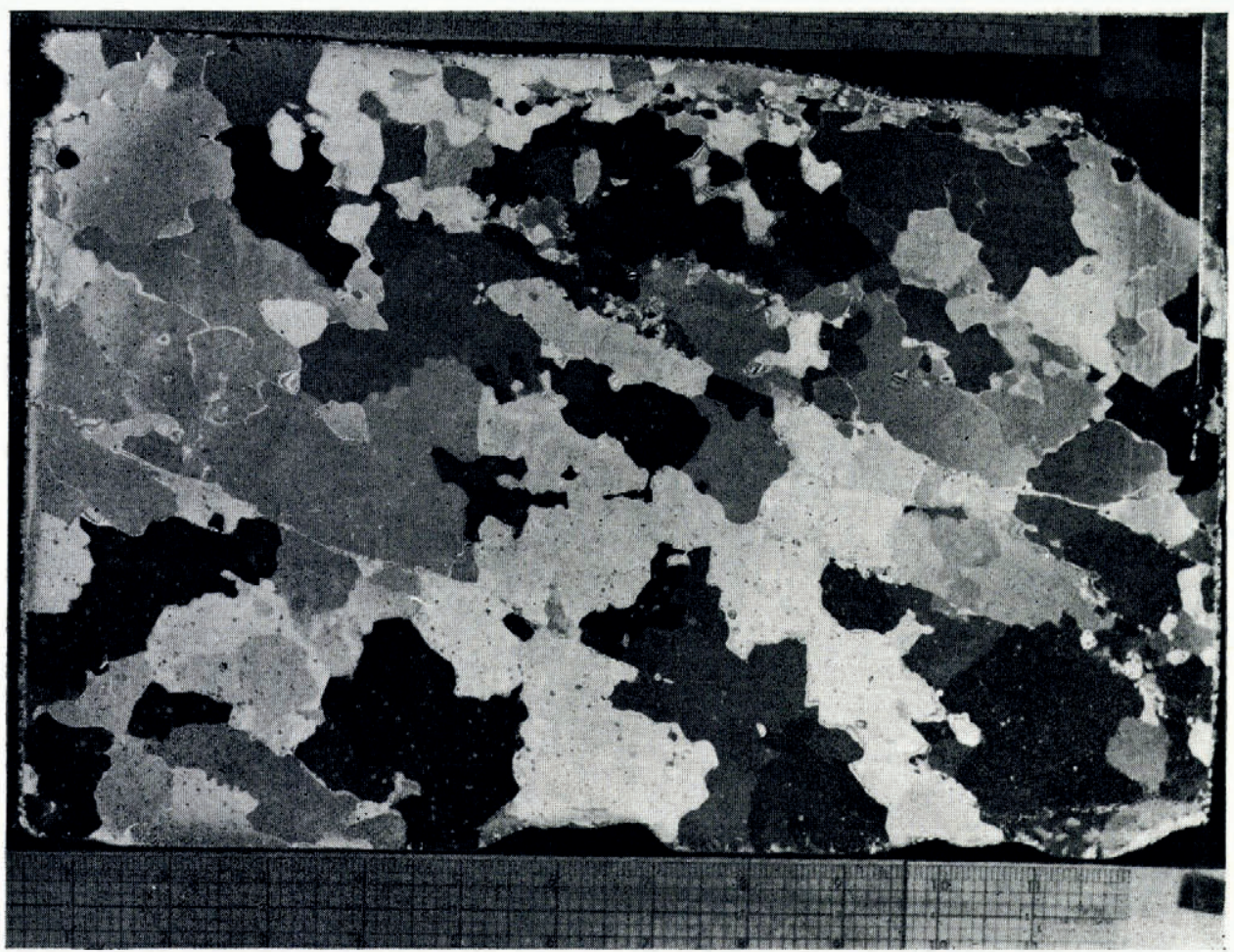

Fig. 2. Section 4 ; rotated $40^{\circ}$ from Figure $I$ 


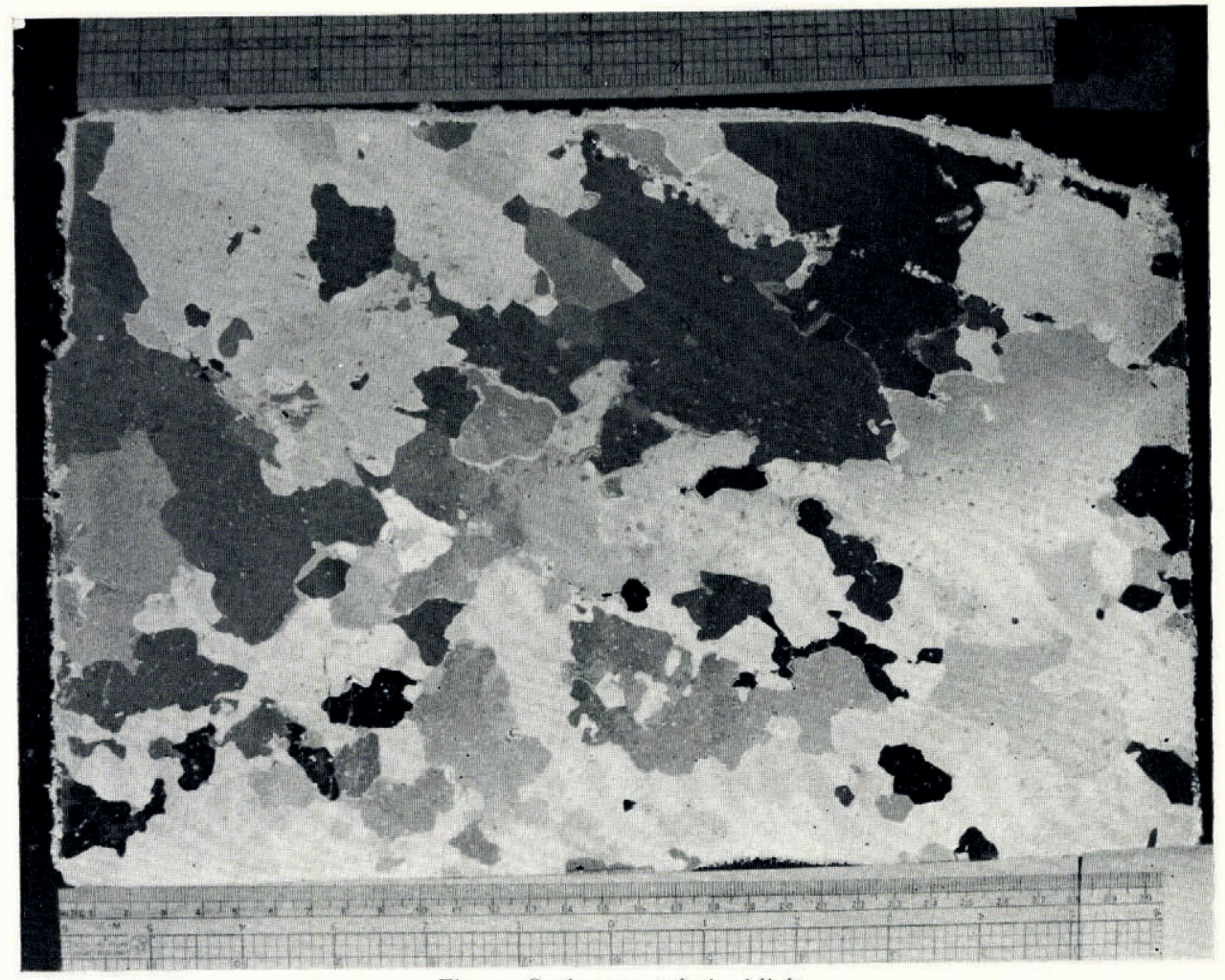

Fig. 3. Section 17 ; polarized light

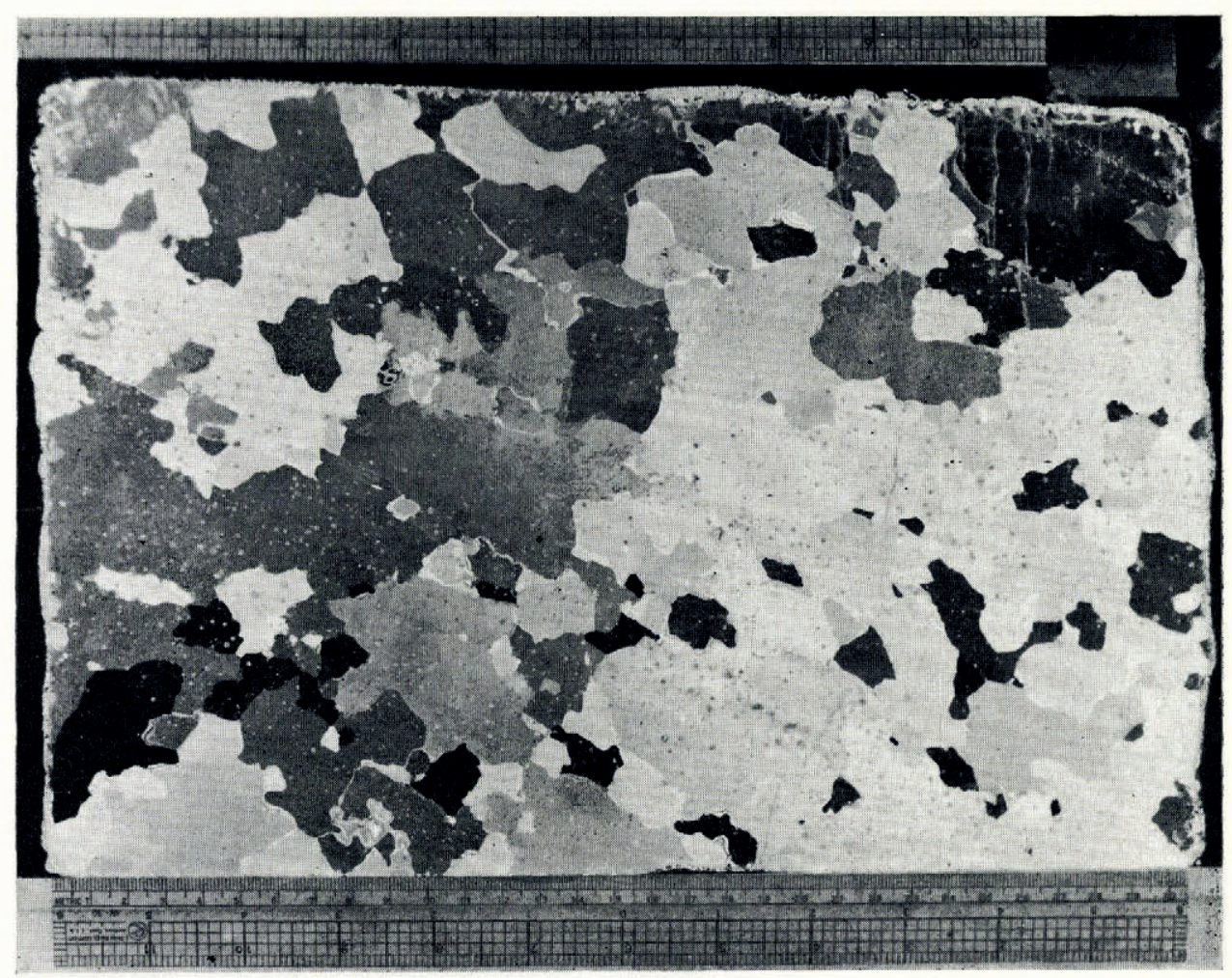

Fig. 4. Section 27; polarized light 


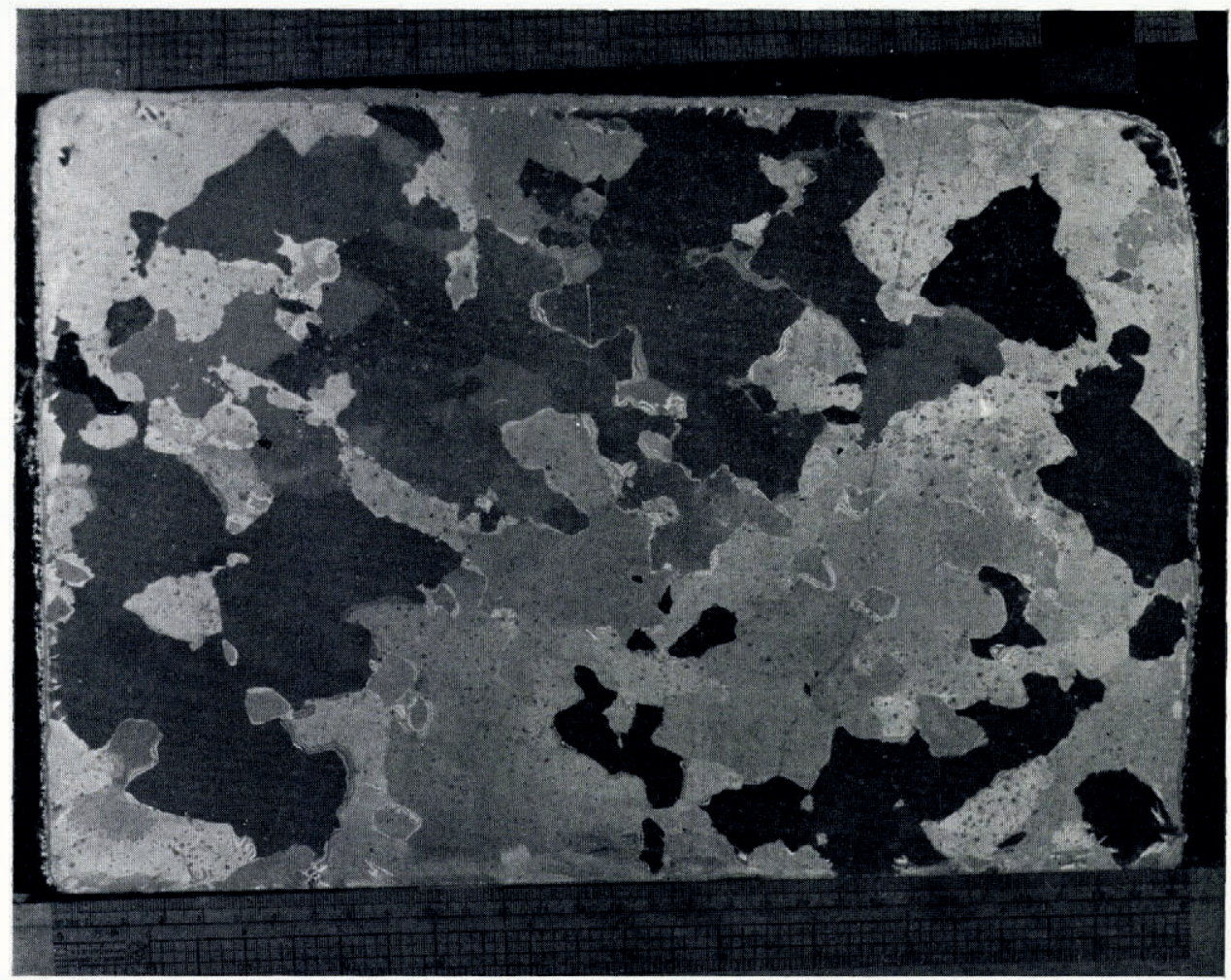

Fig. 5. Section 33; polarized light

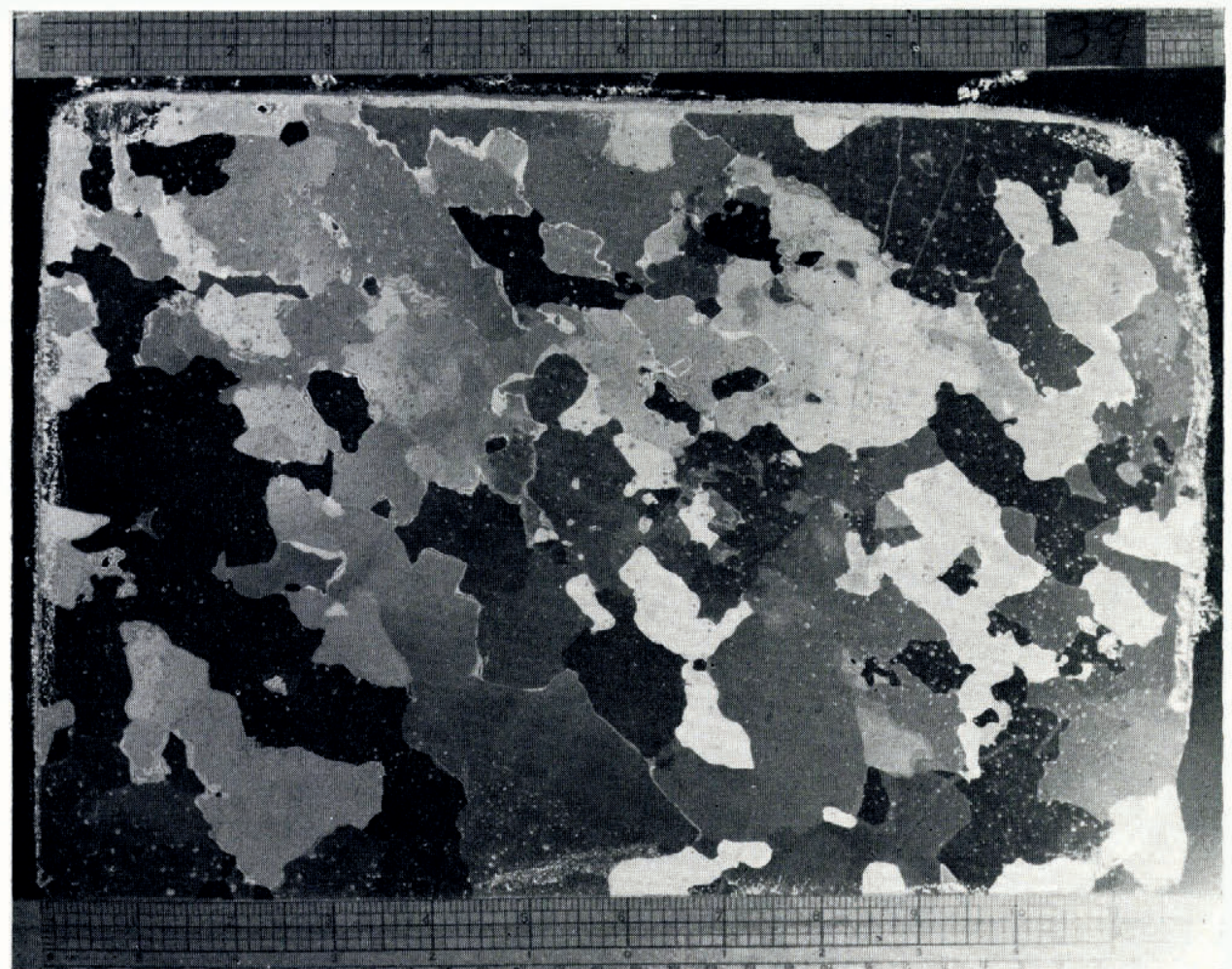

Fig. 6. Section 39; polarized light 
Table I. Crystal A

\begin{tabular}{|c|c|c|c|c|c|c|c|c|c|}
\hline Section & $\mathcal{N}$ & $\begin{array}{c}L \\
\mathrm{~cm}\end{array}$ & $\begin{array}{c}A \\
\mathrm{~cm}^{2}\end{array}$ & $p / A$ & $\begin{array}{c}p \\
\mathrm{~cm}\end{array}$ & $S / V$ & $\begin{array}{c}t \\
\mathrm{~cm}\end{array}$ & $\begin{array}{c}V \\
\mathrm{~cm}^{3}\end{array}$ & $\begin{array}{c}S \\
\mathrm{~cm}^{2}\end{array}$ \\
\hline I & 0 & o & o & - & - & - & 0.490 & o & o \\
\hline 2 & 0 & o & o & - & - & - & 0.410 & o & o \\
\hline 3 & 27 & 8. I & 4.0 & 5.27 & 21.2 & 6.67 & 0.390 & 1. $5^{6}$ & 10.53 \\
\hline 4 & 26 & 21.6 & 10.8 & I.93 & 20.4 & $2.4 \mathrm{I}$ & $0.4^{25}$ & 4.59 & I 1.05 \\
\hline 5 & 33 & 34.4 & 17.2 & $1.5^{1}$ & 25.9 & 1. 92 & 0.400 & 6.88 & 13.20 \\
\hline 6 & 37 & 48.4 & 24.2 & 1.20 & 29.0 & 1. 53 & 0.400 & 9.68 & 14.80 \\
\hline 7 & 42 & 58.2 & 29.1 & I. 13 & 33.0 & $\begin{array}{l}1.44 \\
\end{array}$ & 0.375 & $10.9^{1}$ & I 5.75 \\
\hline 8 & 44 & 69.4 & 34.7 & 1.00 & 34.7 & 1.27 & 0.375 & 13.00 & $16.5^{\circ}$ \\
\hline 9 & 57 & 83.6 & $4^{1} .8$ & I.07 & $44 \cdot 7$ & 1. 36 & 0.360 & 15.05 & $20.5^{2}$ \\
\hline 10 & 69 & 99.0 & 49.5 & 1.09 & 54.1 & 1. 39 & 0.335 & $16.5^{8}$ & 23.12 \\
\hline 11 & 73 & IOI.2 & 50.6 & 1.13 & $57 \cdot 3$ & 1. 44 & 0.375 & 18.97 & 27.37 \\
\hline 12 & 68 & 110.8 & 55.4 & 0.96 & 53.4 & 1.23 & $0.4^{10}$ & 22.71 & 27.88 \\
\hline 13 & 66 & 105.8 & $5^{2.9}$ & $0.9^{8}$ & 51.8 & 1.25 & $0.44^{\circ}$ & 23.28 & 29.04 \\
\hline 14 & 81 & 110.8 & $55 \cdot 4$ & 1.15 & $6_{3.6}$ & 1.46 & 0.455 & 25.21 & 36.85 \\
\hline 15 & 82 & 112.8 & 56.4 & 1.14 & $64 \cdot 4$ & I. 45 & 0.445 & 25.10 & 36.49 \\
\hline 16 & 98 & 118.0 & 59.0 & 1.30 & 77.0 & 1.66 & 0.410 & 24.19 & 40.18 \\
\hline 17 & 110 & I 28.8 & 64.4 & 1.34 & 86.4 & 1.71 & 0.395 & 25.44 & 43.45 \\
\hline 18 & 135 & 128.6 & $64 \cdot 3$ & 1. 65 & 106.0 & 2.10 & $0.43^{\circ}$ & 27.65 & 58.05 \\
\hline 19 & 110 & 102.8 & $5^{1.4}$ & 1. 68 & 86.4 & 2.14 & $0.45^{\circ}$ & 23.13 & $49.5^{\circ}$ \\
\hline 20 & 125 & 107.2 & 53.6 & 1.83 & 98.2 & 2.33 & 0.455 & 24.39 & $5^{6.87}$ \\
\hline 21 & 135 & 119.2 & 59.6 & 1.78 & 106.3 & 2.26 & $0.55^{\circ}$ & 32.78 & 74.25 \\
\hline 22 & 120 & 141.8 & 70.9 & 1.33 & $94 \cdot 3$ & I. 69 & 0.675 & 47.86 & 81.00 \\
\hline 23 & 140 & ${ }^{1} 6_{5} .0$ & 82.5 & 1. 33 & 110.0 & 1.70 & 0.560 & 46.20 & 78.40 \\
\hline 24 & $15^{\circ}$ & 137.4 & 68.7 & 1.70 & I I 7.8 & 2.18 & 0.430 & 29.54 & $64.5^{\circ}$ \\
\hline 25 & 149 & 138.2 & 69.1 & 1.70 & 117.0 & 2.16 & 0.445 & 30.75 & 66.30 \\
\hline 26 & 145 & 121.0 & 60.5 & 1.88 & 114.0 & $2.4^{\circ}$ & 0.460 & 27.83 & 66.70 \\
\hline 27 & $\begin{array}{l}120 \\
120\end{array}$ & 112.8 & 56.4 & 1.67 & 94.6 & 2.13 & $0.4^{60}$ & 25.94 & 55.20 \\
\hline 28 & 110 & 112.4 & 56.2 & I. 54 & 86.4 & I. 96 & $0.43^{\circ}$ & 24.17 & $47.3^{\circ}$ \\
\hline 29 & I I I & 1 16.8 & 58.4 & I. 49 & 87.2 & 1.90 & 0.410 & 23.94 & $45 \cdot 5^{I}$ \\
\hline 30 & 120 & 107.6 & 53.8 & 1. 79 & $94 \cdot 3$ & 2.23 & 0.405 & 21.79 & 48.60 \\
\hline $3^{1}$ & 123 & I02.8 & $5^{1} \cdot 4$ & 1. 88 & 96.6 & 2.39 & 0.480 & 24.67 & 59.04 \\
\hline $3^{2}$ & 88 & 65.6 & 32.8 & 2.10 & 69.1 & 2.68 & 0.475 & $15.5^{8}$ & 41.80 \\
\hline 33 & 67 & 53.1 & 26.6 & 1.99 & 52.7 & $2.5^{2}$ & 0.505 & $13.4 \mathrm{I}$ & 33.84 \\
\hline 34 & 49 & $5^{0.4}$ & 25.2 & 1.54 & 38.5 & 1. 94 & 0.500 & 12.60 & $24.5^{\circ}$ \\
\hline 35 & 53 & 45.6 & 22.8 & 1.82 & 41.6 & $2.3^{2}$ & 0.375 & 8.55 & 19.88 \\
\hline 36 & $6 \mathrm{I}$ & 52.0 & 26.0 & 1.84 & 47.8 & 2.34 & $0.45^{\circ}$ & 11.70 & 27.45 \\
\hline 37 & 68 & 46.0 & 23.0 & 2.32 & $53 \cdot 4$ & 2.87 & $0.5^{25}$ & I 2.08 & 35.70 \\
\hline $3^{8}$ & 63 & 58.4 & 29.2 & 1.70 & 49.5 & 2.16 & 0.510 & 14.89 & 32.13 \\
\hline 39 & $5^{8}$ & $4^{2.0}$ & 21.0 & 2.16 & 45.5 & 2.76 & 0.460 & 9.66 & 26.68 \\
\hline 40 & 47 & 29.8 & 14.9 & $2.4^{8}$ & 36.9 & 3.15 & $0.44^{\circ}$ & 6.55 & 20.68 \\
\hline 41 & $3^{6}$ & 25.4 & 12.7 & 2.23 & 28.3 & 2.83 & 0.480 & 6.10 & I 7.28 \\
\hline $4^{2}$ & 19 & 9.2 & 4.6 & 3.24 & I 4.9 & 4.13 & 0.530 & 2.44 & 10.07 \\
\hline 43 & 14 & $7 \cdot 4$ & 3.7 & 2.98 & I1. & 3.78 & 0.555 & 2.05 & $7 \cdot 77$ \\
\hline 44 & 16 & 8.2 & 4.1 & $3 \cdot 3^{6}$ & 1 3.8 & 3.90 & $0.53^{\circ}$ & 2.17 & $8.4^{8}$ \\
\hline 45 & 11 & 7.8 & $3 \cdot 9$ & 2.20 & 8.6 & 2.82 & $0.49^{\circ}$ & I.9I & $5 \cdot 39$ \\
\hline $4^{6}$ & 10 & 8.o & 4.0 & 1. $9^{8}$ & $7 \cdot 9$ & $2.5^{\circ}$ & $0.5^{15}$ & 2.06 & 5.15 \\
\hline 47 & 5 & 3.0 & 1. 5 & 2.60 & $3 \cdot 9$ & $3 \cdot 33$ & $0.55^{\circ}$ & 0.82 & 2.75 \\
\hline 48 & 3 & 0.6 & 0.3 & 8.00 & 2.4 & 10.00 & 0.555 & 0.17 & г. 66 \\
\hline \multirow[t]{2}{*}{ (49) } & 0 & o & o & & o & & $0.29^{\circ}$ & o & o \\
\hline & 3374 & 3437.0 & I 718.5 & & $265_{1} .8$ & & 22.265 & 776.53 & I 539.16 \\
\hline
\end{tabular}

From total $\mathcal{N}$ and $L$ :

$$
\begin{aligned}
& \frac{p}{A}=\frac{\pi \mathcal{N}}{2 L}=\frac{\pi(3374)}{2(3437)}=\mathrm{1} .54^{2} \\
& \frac{S}{V}=\frac{\mathrm{I} 539 \cdot 16}{776.53}=1.982
\end{aligned}
$$


Table II. Crystal B

\begin{tabular}{|c|c|c|c|c|c|c|c|c|c|}
\hline Section & $\mathcal{N}$ & $\begin{array}{c}L \\
\mathrm{~cm}\end{array}$ & $\begin{array}{c}A \\
\mathrm{~cm}^{2}\end{array}$ & $p / A$ & $\begin{array}{c}p \\
\mathrm{~cm}\end{array}$ & $S / V$ & $\begin{array}{c}t \\
\mathrm{~cm}\end{array}$ & $\begin{array}{c}V \\
\mathrm{~cm}^{3}\end{array}$ & $\begin{array}{c}S \\
\mathrm{~cm}^{2}\end{array}$ \\
\hline I & 0 & o & o & - & - & - & $0.49^{\circ}$ & 0 & o \\
\hline 2 & o & o & o & - & - & 一 & 0.410 & 0 & o \\
\hline 3 & 0 & o & o & - & - & - & 0.390 & o & o \\
\hline 4 & 12 & 2.6 & 1. 3 & 7.27 & $9 \cdot 4$ & 9.23 & 0.425 & 0.55 & 5.10 \\
\hline 5 & 12 & 5.6 & 2.8 & $3 \cdot 3^{8}$ & $9 \cdot 4$ & 4.29 & 0.400 & I. 12 & 4.80 \\
\hline 6 & 25 & I I. 6 & 5.8 & $3 \cdot 39$ & 19.6 & $4 \cdot 35$ & 0.400 & $2.3^{2}$ & 10.00 \\
\hline 7 & 37 & 16.2 & 8.1 & 3.59 & 29.0 & $4 \cdot 56$ & 0.375 & 3.04 & 13.88 \\
\hline 8 & 59 & 27.6 & 13.8 & $3 \cdot 3^{6}$ & 46.3 & 4.28 & 0.375 & 5.17 & 22.12 \\
\hline 9 & $4^{6}$ & 35.8 & 17.9 & 2.02 & 36.1 & 2.57 & 0.360 & 6.44 & 1 6.56 \\
\hline 10 & 55 & 46.6 & $23 \cdot 3$ & 1. 86 & 43.2 & $2 \cdot 36$ & 0.335 & $7.8 \mathrm{i}$ & 18.42 \\
\hline II & 81 & 63.4 & 31.7 & 2.01 & 63.6 & 2.55 & 0.375 & I 1.89 & $3^{0.3^{8}}$ \\
\hline 12 & 80 & 76.0 & 38.0 & 1. 64 & 62.8 & 2.08 & 0.410 & ${ }^{1} 5.5^{8}$ & 32.80 \\
\hline 13 & 112 & 86.6 & $43 \cdot 3$ & 2.04 & 87.9 & 2.59 & $0.44^{\circ}$ & $19.5^{2}$ & 49.28 \\
\hline 14 & 162 & 114.8 & 57.4 & 2.22 & 127.1 & 2.82 & 0.455 & 26.12 & $73.7 \mathrm{I}$ \\
\hline${ }^{1} 5$ & 170 & 165.8 & 82.9 & I. 61 & 133.4 & 2.05 & 0.445 & 36.89 & 75.65 \\
\hline 16 & 164 & 171.8 & $85 \cdot 9$ & 1.50 & 128.7 & I. $9 \mathrm{I}$ & $0.4^{10}$ & 35.22 & 67.24 \\
\hline 17 & 163 & 187.4 & $93 \cdot 7$ & 1.37 & 128.0 & 1.74 & 0.395 & 37.01 & $64 \cdot 39$ \\
\hline I 8 & 206 & 207.8 & 103.9 & 1. $5^{6}$ & 161.8 & 1. 98 & $0.43^{\circ}$ & 44.68 & $88.5^{8}$ \\
\hline 19 & I93 & $209 \cdot 4$ & 104.7 & 1.45 & ${ }^{1} 5^{1.5}$ & 1. .84 & $0.45^{\circ}$ & $47 \cdot 12$ & $86.8_{5}$ \\
\hline 20 & 190 & 237.0 & I 18.5 & 1. 26 & I $49 \cdot 3$ & 1.60 & 0.455 & 53.92 & 86.45 \\
\hline $2 \mathrm{I}$ & 267 & 230.1 & 115.1 & 1. 82 & 209.7 & 2.32 & $0.55^{\circ}$ & 63.28 & 146.85 \\
\hline 22 & 296 & 270.8 & 135.4 & 1.72 & 232.2 & 2.18 & o. 675 & $9^{1} \cdot 39$ & I 99.80 \\
\hline 23 & 288 & 267.4 & 133.7 & 1. 69 & 226.1 & 2.15 & 0.560 & 74.87 & 161.28 \\
\hline 24 & $3^{19}$ & 286.2 & $143 . \mathrm{I}$ & 1. 75 & 250.6 & 2.23 & $0.43^{\circ}$ & 61.53 & 137.17 \\
\hline 25 & 337 & 306.4 & I 53.1 & 1.74 & 264.9 & 2.20 & 0.445 & 68.17 & 149.96 \\
\hline 26 & $33^{6}$ & 294.8 & 147.4 & 1.79 & 264.0 & 2.28 & 0.460 & 67.80 & I $54.5^{6}$ \\
\hline 27 & 335 & 372.8 & 186.4 & $1.4^{\mathrm{I}}$ & 263.4 & 1.80 & $0.4^{60}$ & 85.74 & 154.10 \\
\hline 28 & 362 & 395.6 & 197.8 & 1.44 & 284.0 & 1. 83 & 0.430 & 85.05 & I 55.66 \\
\hline 29 & 373 & 408.0 & 204.0 & 1.44 & 292.8 & 1. 83 & $0.4^{10}$ & 83.64 & ${ }^{1} 5^{2} .93$ \\
\hline 30 & 395 & 400.8 & 200.4 & 1.55 & 310.3 & 1.97 & 0.405 & 8 เ.16 & I 59.78 \\
\hline $3^{I}$ & $3^{69}$ & 371.2 & 185.6 & 1. 56 & 289.0 & г.99 & 0.480 & 89.09 & 177.12 \\
\hline $3^{2}$ & $35^{6}$ & 337.6 & 168.8 & 1. 66 & 279.4 & 2.11 & 0.475 & 80.18 & 169.10 \\
\hline 33 & 335 & 318.3 & 159.1 & I. 65 & 263.4 & 2.10 & 0.505 & 80.37 & 169.17 \\
\hline 34 & 295 & 276.2 & 138.1 & 1.68 & 231.6 & 2.14 & 0.500 & 69.05 & $147.5^{\circ}$ \\
\hline 35 & 279 & 259.0 & 129.5 & 1.69 & 219.0 & 2.15 & 0.375 & $48.5^{6}$ & 104.63 \\
\hline $3^{6}$ & 285 & 248.0 & 124.0 & I. 80 & 233.7 & 2.30 & $0.45^{\circ}$ & 55.80 & 128.25 \\
\hline 37 & $3^{2 \mathrm{I}}$ & 267.2 & 133.6 & 1.89 & 251.9 & 2.40 & $0.5^{25}$ & 70.14 & $168.5^{2}$ \\
\hline $3^{8}$ & $34^{8}$ & 294.6 & 147.3 & 1.86 & 273.1 & 2.36 & 0.510 & 75.12 & $177.4^{8}$ \\
\hline 39 & 353 & 319.0 & 159.5 & I. 74 & 277.0 & $2.2 \mathrm{I}$ & 0.460 & $73 \cdot 37$ & $162.3^{8}$ \\
\hline 40 & $3^{61}$ & 326.6 & I 63.3 & I. 74 & 283.6 & $2.2 \mathrm{I}$ & $0.44^{\circ}$ & 71.85 & ${ }^{1} 5^{8.8}$ \\
\hline $4^{1}$ & 326 & 287.0 & 143.5 & 1.78 & $25^{6.1}$ & 2.27 & 0.480 & 68.88 & 156.48 \\
\hline 42 & 322 & 265.6 & 132.8 & 1.94 & $25^{2} .9$ & $2.4^{2}$ & $0.53^{\circ}$ & $70 \cdot 3^{8}$ & 170.66 \\
\hline 43 & 324 & 204.6 & 102.3 & 2.49 & 254.6 & 3.17 & 0.555 & 56.78 & I 79.82 \\
\hline 44 & $29^{2}$ & 208.2 & 104.1 & 2.20 & 229.5 & $2.8 \mathrm{I}$ & $0.53^{\circ}$ & 55.17 & 154.76 \\
\hline 45 & 269 & 197.0 & 98.5 & 2.15 & 211.1 & 2.75 & $0.49^{\circ}$ & 48.26 & $131.8 \mathrm{I}$ \\
\hline 46 & 247 & 223.2 & I I I 6 & I. 74 & I 94.0 & 2.21 & $0.5^{15}$ & $57 \cdot 47$ & 127.20 \\
\hline 47 & 243 & 258.0 & 129.0 & I. 48 & 190.8 & I. 88 & $0.55^{\circ}$ & 70.95 & ${ }^{1} 33.65$ \\
\hline 48 & 197 & 254.8 & 127.4 & 1.22 & 154.8 & 1.55 & 0.555 & 70.71 & I09.34 \\
\hline \multirow[t]{2}{*}{ (49) } & & & $\dagger_{122.5}$ & & & $*_{1.55}$ & 0.290 & $35 \cdot 5^{2}$ & $54.8 \mathrm{I}$ \\
\hline & 597 & 98 I 5.0 & 4907.5 & & 8330.6 & & 22.265 & $23^{64.7^{2}}$ & 5100.02 \\
\hline
\end{tabular}

* Assumed.

$\dagger$ From Chart I; not included in total.

$\frac{p}{A}=\frac{8330.6}{4907.5}=1.697$ (for the 45 sections which contain part of the crystal)

$\frac{p}{A}=\frac{\pi \mathcal{N}}{2 L}=\frac{\pi(\text { 1 } 579)}{2(9815)}=$ 1.696

$\frac{S}{V}=\frac{5100.02}{2364.72}=2.157$ 


\section{Observations}

Using the above procedure, it became evident that many grains seemingly separate in one thin section were actually part of the same crystal. Therefore, two complex crystals were selected for complete determination of size and shape. These are identified by patterns, and the letters " $A$ " and "B", in the eight section tracings reproduced (Figs. 7-I4) as representative of the total 48 sections made. Tracings of all 48 sections are reproduced elsewhere (Rigsby, in press).

It was hoped that at least one of these crystals would be complete within the sample block. Although the smaller crystal A appears to be nearly complete, it touched the edge of the block in two places. Even though it cannot be demonstrated that these lateral extensions did not expand to larger size outside the sample block, this crystal is believed to be representative of a complete crystal. It had a volume of nearly $800 \mathrm{~cm}^{3}$.

The larger crystal composed over i 6 per cent of the total sample, and it was certainly not complete as it was cut by four sides of the block. Its volume within the sample block was nearly $2400 \mathrm{~cm}^{3}$. In the bottom section (No. 48), this crystal still covered $127 \mathrm{~cm}^{2}$. It was so complex in section 45 that it was cut 33 times in the one $32 \times 21 \mathrm{~cm}$ thin section. Sections 33 , 39 and 47 each cut it 20 or more times. The crystals intertwine so extensively that the assemblage resembles a bowl of spaghetti, frozen and then sliced. They are, in fact, even more complicated, because they branch many times and exhibit great changes in thickness.

Crystals illustrated in other patterns and identified by letters on the drawings (Figs. 7-I4) had essentially the same orientation of their optic axes as crystals $\mathrm{A}$ and $\mathrm{B}$, but they could not be found actually to join anywhere in the sample block. It is possible that some of these may have joined outside the block as many of the crystals were not complete.

The orientation of the grains identified as $\mathrm{C}$ was only $2-5^{\circ}$ from the very large crystal $\mathrm{B}$. This was well within the spread of the axis orientations of $\mathrm{B}$, but wherever the two grains were seen in juxtaposition, a definite boundary was present. The grains labeled $\mathrm{D}$ have the same orientation as crystal B, and even though no connection or juxtaposition was seen in any of the sections, these crystals may also have joined outside the sample.

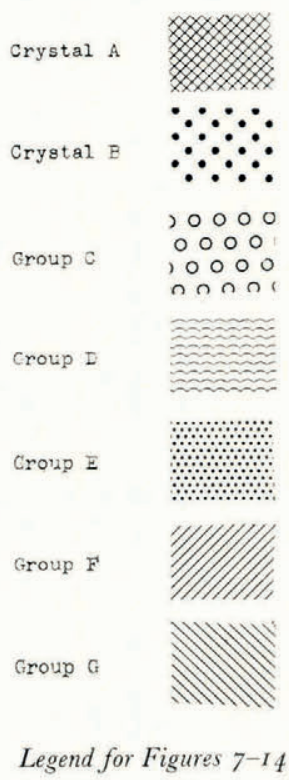




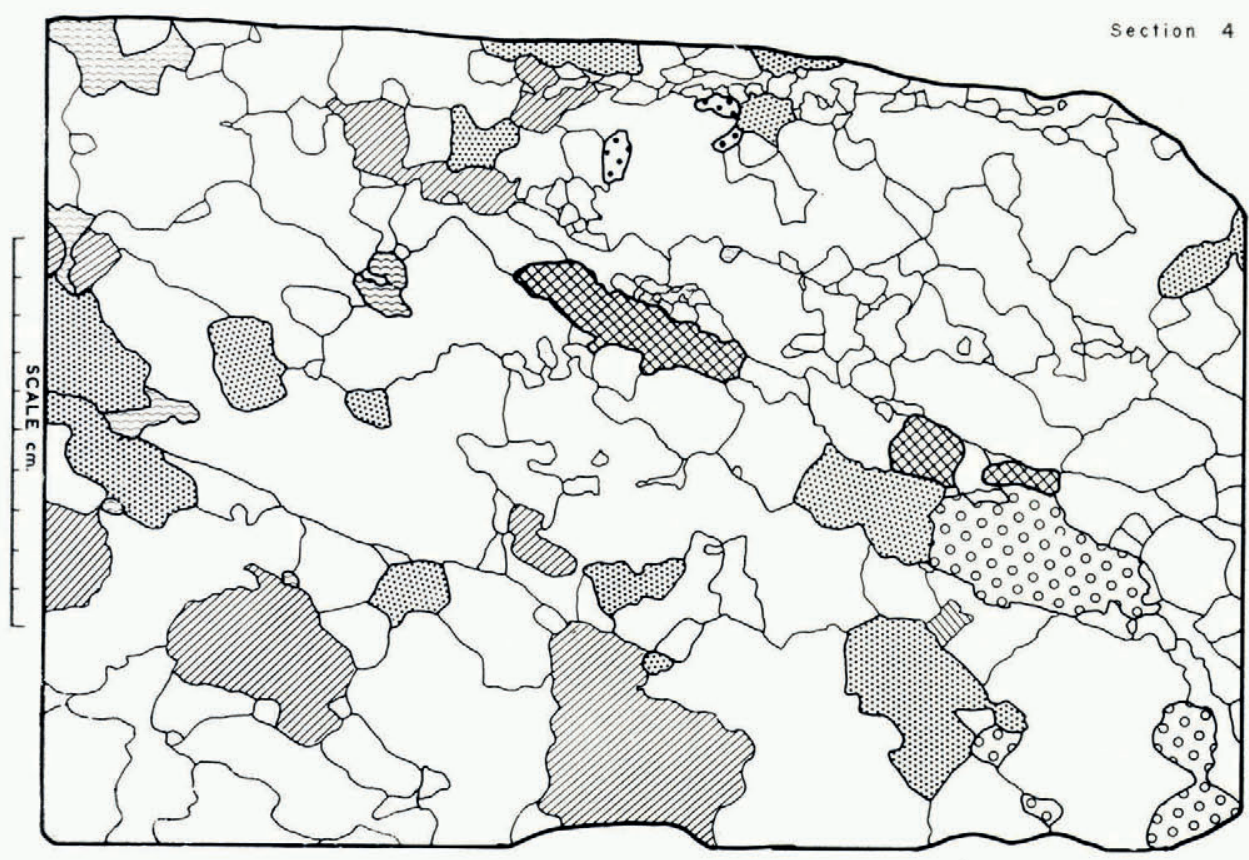

Fig. 7

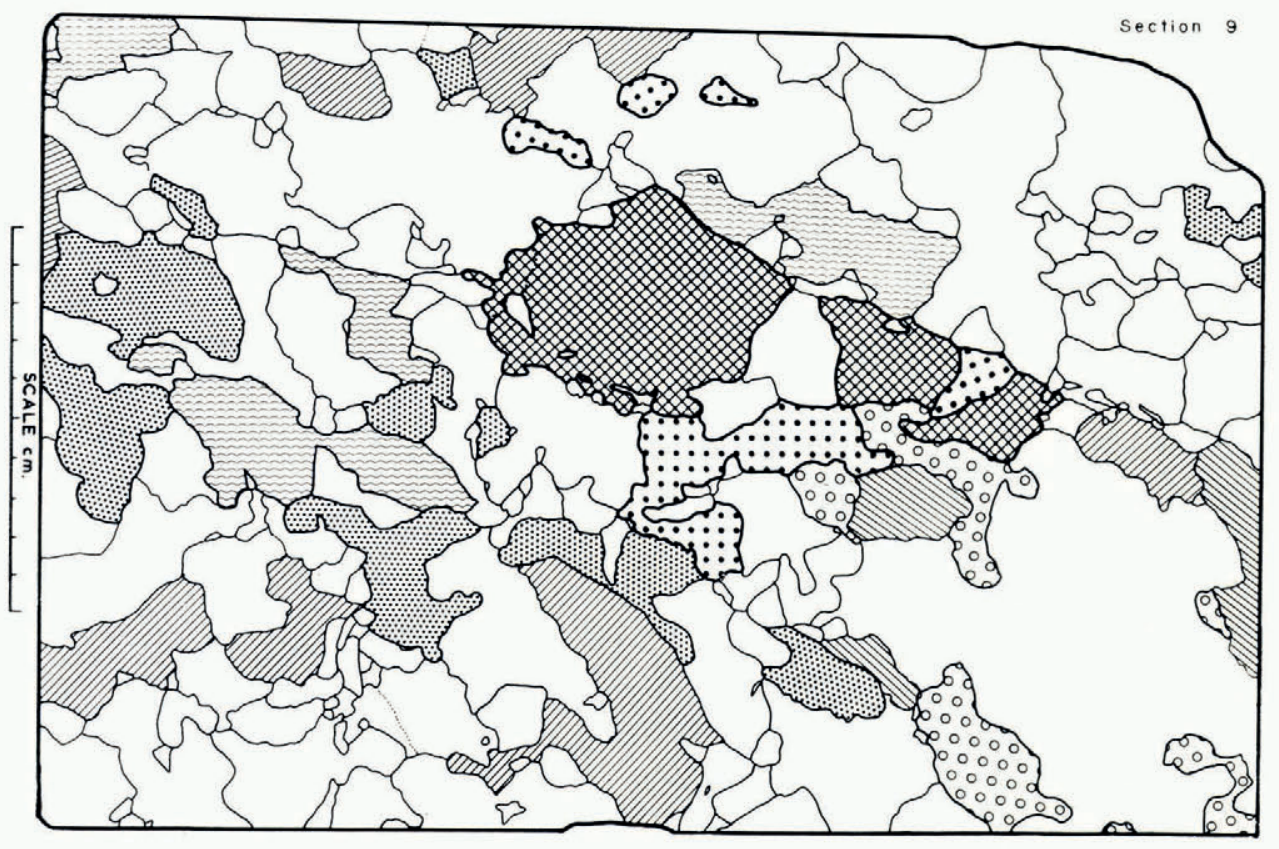

Fig. 8 


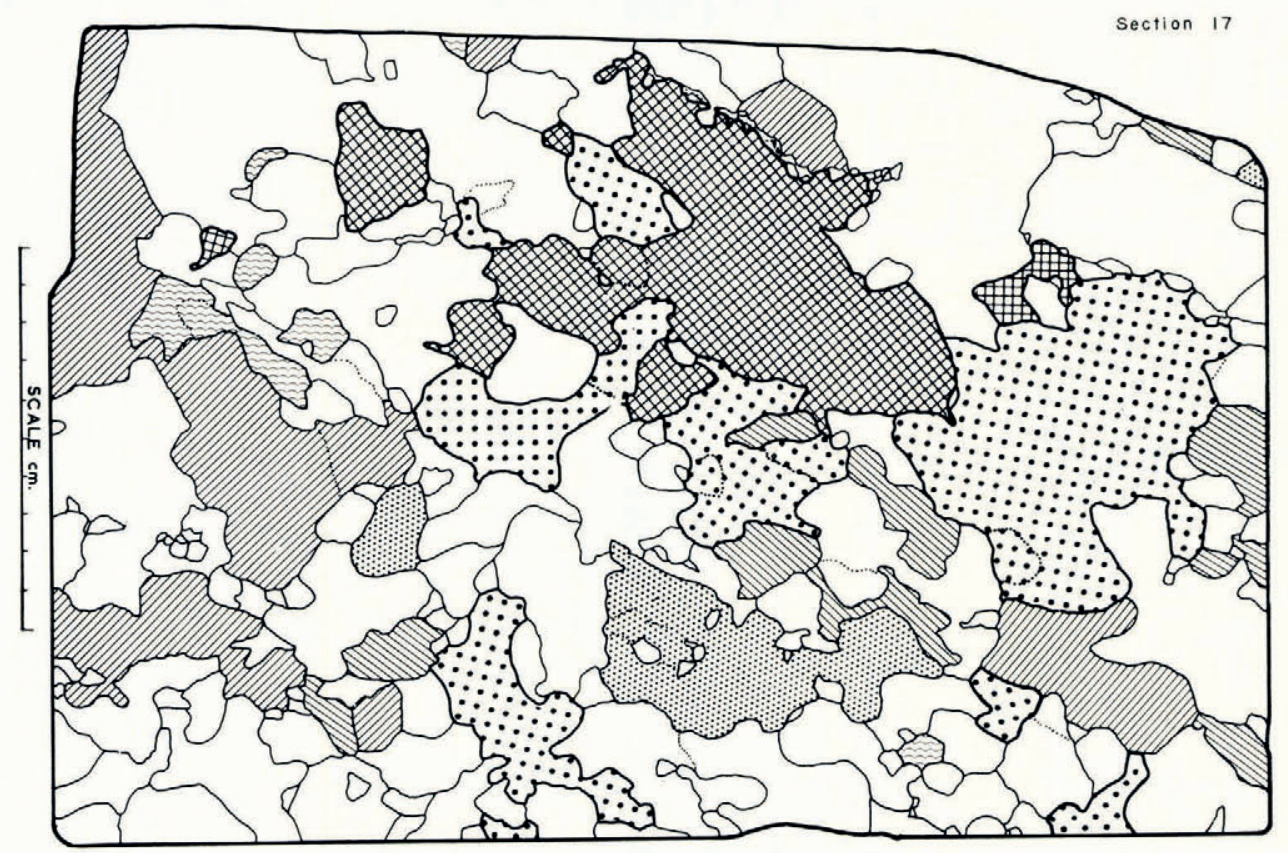

Fig. 9

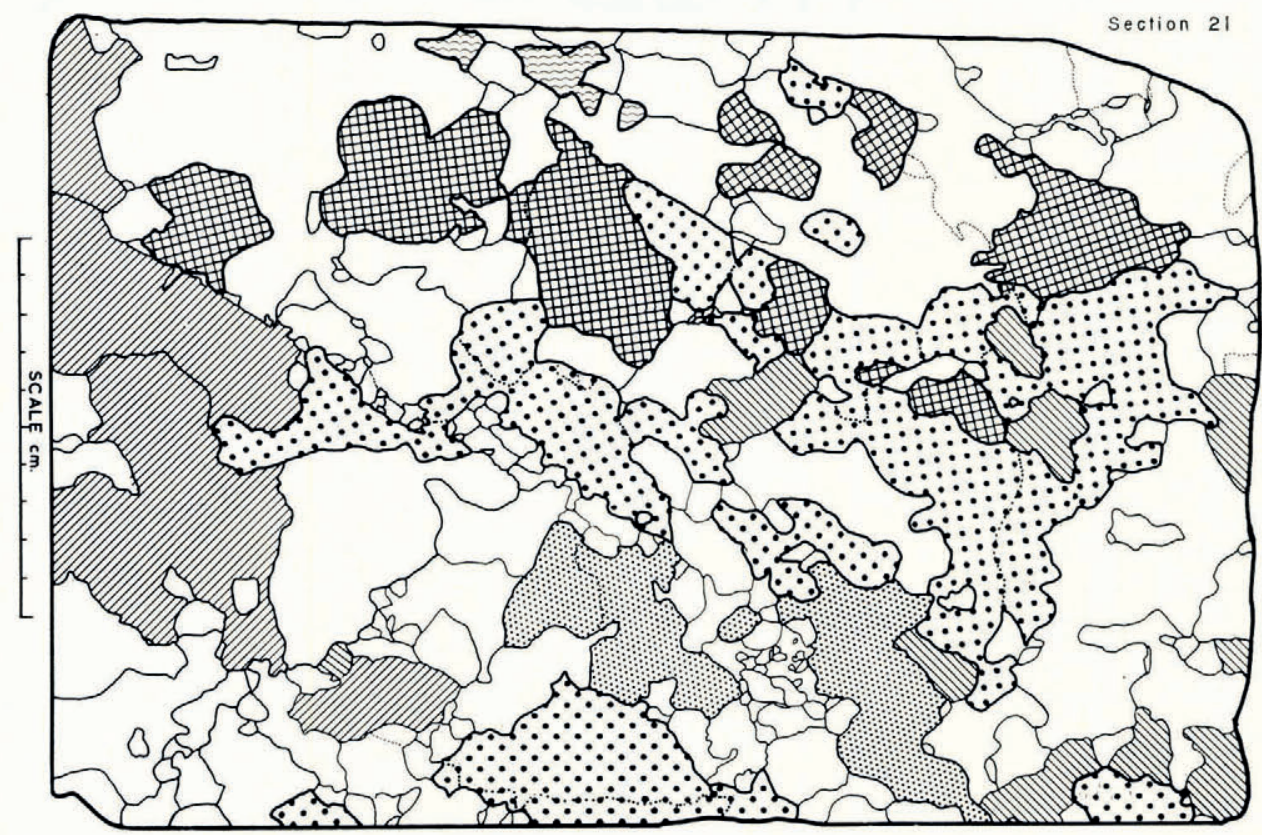

Fig. IO 


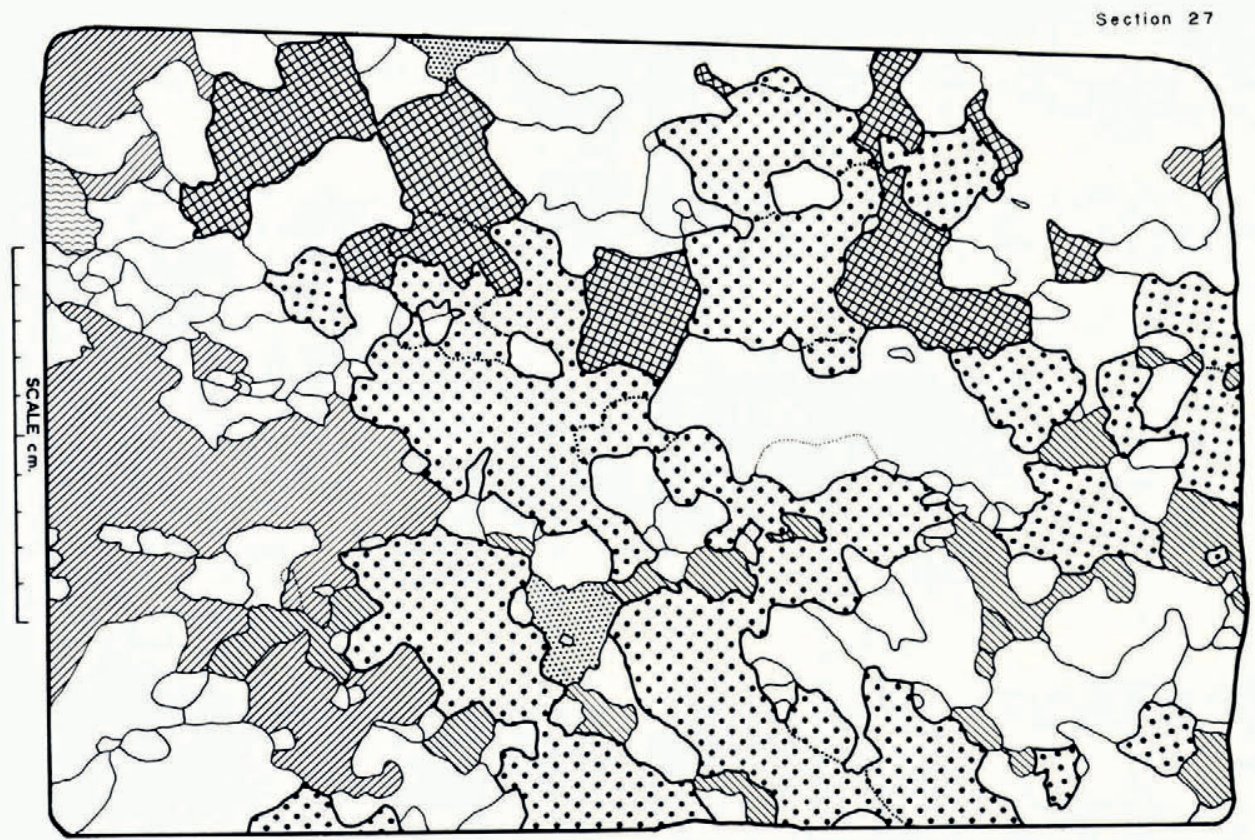

Fig. II

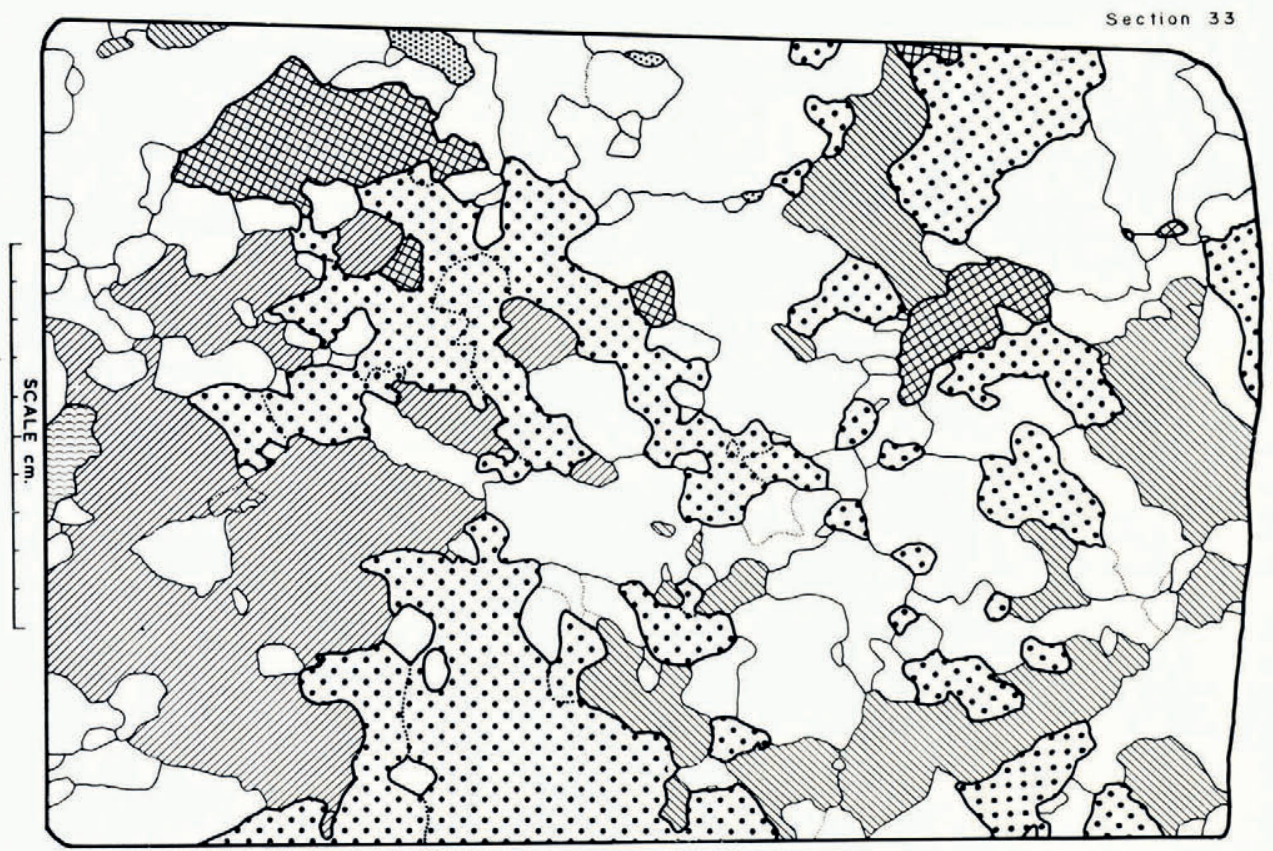

Fig. I 2 


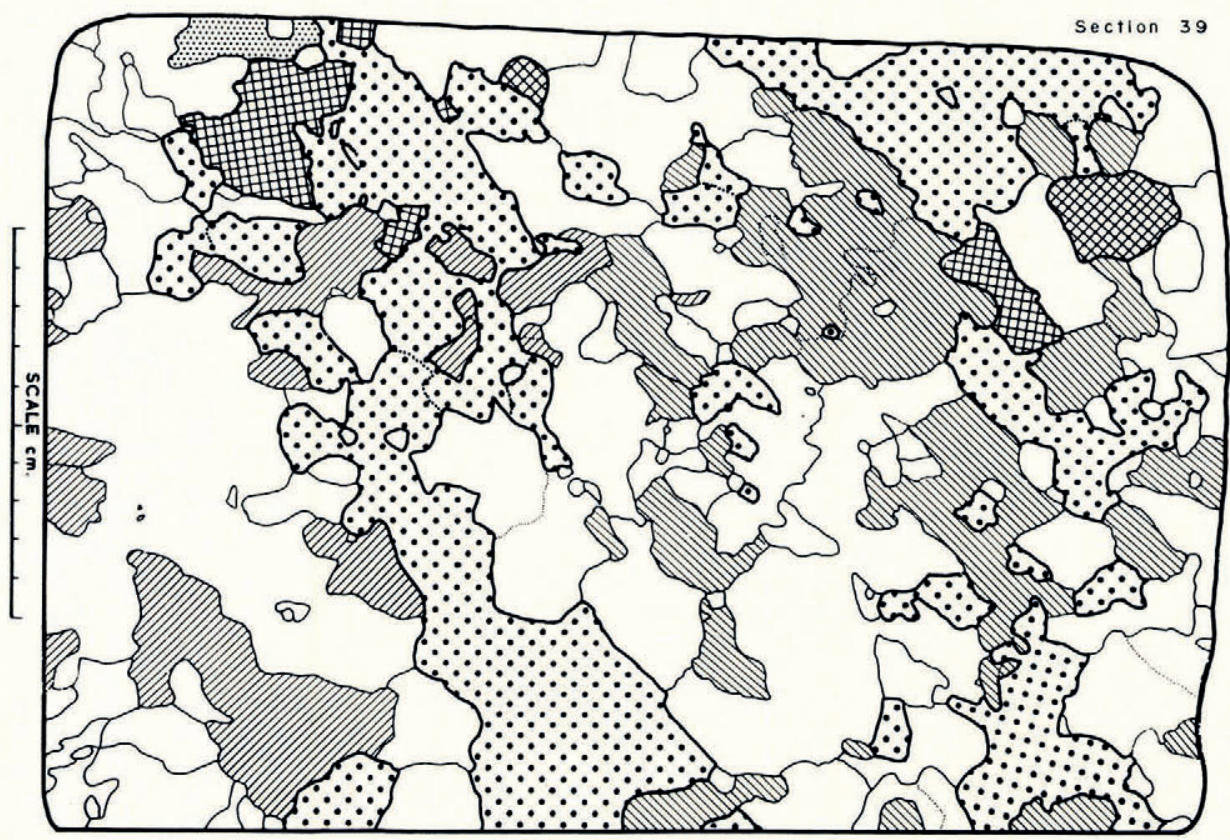

Fig. 13

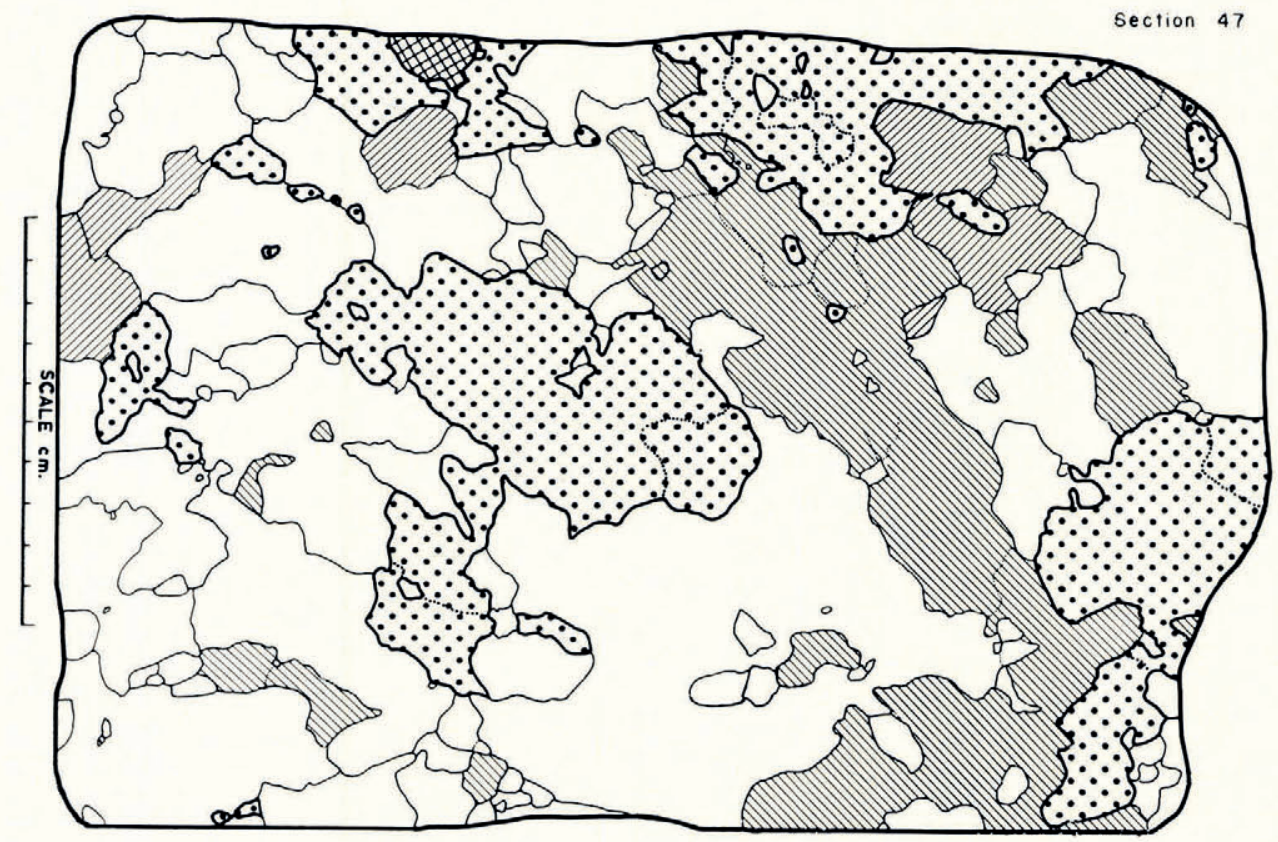

Fig. I4 
The axes of grains identified as $\mathrm{E}$ on the drawings all seemed to range within about ${ }_{10-1} 2^{\circ}$ of crystal B, some having greater and some lesser azimuths, while others had about the same azimuth but had about $10^{\circ}$ less inclination to the horizontal or section surface. The orientation of the axes of this group seemed too different from that of crystal B to be considered part of it.

The axes of the $\mathrm{F}$ group of grains had azimuths almost the same as or smaller than those of crystal A, while those of the $\mathrm{G}$ group had somewhat larger azimuths. The various measurements on crystal A throughout all sections gave the axes as nearly horizontal. Crystal A and groups $\mathrm{F}$ and $\mathrm{G}$ might comprise another system of related crystals with nearly parallel axes similar to crystal B and groups C and D.

The drawings can be compared with the photographs for better understanding of the text. Figures $\mathrm{I}$ and 2 show the two different orientations between the crossed polaroid sheets of section 4. Compare these with the drawing of section 4 in Figure 7. The interference colors (shades of gray in the photographs) of the various grains which are shown as part of the same crystal vary slightly due to some variation in thickness from one side to another and also due to the conoscopic effect when photographing a large section with a relatively wide-angle lens.

It is known that crystal axes in strongly stressed ice become aligned such that movement can take place along basal glide planes (Rigsby, I955, I96o). However, very little is yet known about such orientation control during recrystallization near the surface of the glacier. Rigsby (I95 I, I960) has already published information concerning the preferred orientation of the optic axes in temperate glaciers, where it is almost certain that considerable recrystallization had occurred after deformation, and in polar glaciers where the evidence is strong that little or no recrystallization occurred after deformation.

Study of all crystal orientations reveals only a few major orientations in this sample. This indicates that nearly all grains as seen in each cut may be parts of only a few large crystals. Approximately all but 4 per cent of the crystals by area were within five major orientations. In most instances, the spread in orientation of the optic axes in each of these major divisions was somewhat greater than that found throughout the span of single crystals; however, the fact that all were so closely aligned indicates some relatedness. One might speculate that there are relatively few crystals in the entire coarse-grained part of a temperate glacier.

In a single crystal extending over distances of $30 \mathrm{~cm}$ or more, the orientation of the optic axis ranges at least $10^{\circ}$. In many instances the bifurcated parts of crystals rejoin but with a discernible boundary (Fig. I5). As illustrated in the drawing, there is sufficient difference in orientation between $a$ and $b$, and $c$ and $d$, to permit a crystal boundary, but a continuous path

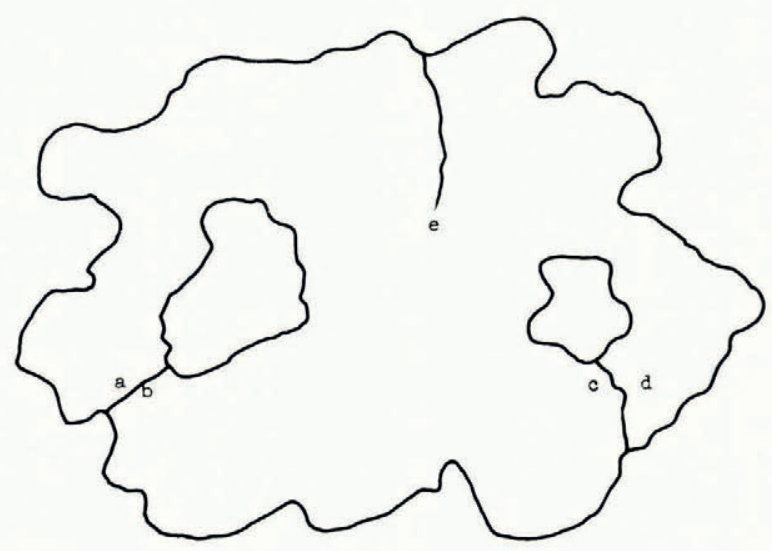

Fig. 15. A representation of a crystal in thin section; a composite of several features not necessarily shown in any one section 
can be traced from $a$ to $b$ around another crystal (usually a longer distance than shown in the two-dimensional drawing. In laboratory deformation studies (Rigsby, 1960), single crystals of ice were bent with a large change in the orientation of the optic axis. It has been generally assumed that recrystallization usually relieves this change in orientation, but with such complicated shapes it is not surprising that a gradual orientation change of $10^{\circ}$ may occur.

In many instances a slight change in orientation of the parts of a single crystal could be related to a perceptible line in the next section (either above or below). Conversely, in at least two instances, a faint boundary near the margin disappeared in the interior of the crystal in the observed section as illustrated in Figure i 5 at $e$.

With so few single crystals in the sample, it was obvious that the original plan to obtain the distribution function according to grain-size could not be made, but showing the actual shape and volume of a few single crystals made it worth while to complete the study.

\section{Parameters Used in This Study}

Rosiwal analyses have been used by petrographers for many years to make quantitative measurements of volume percentages of various phases in rocks. The length of a line or grid of lines crossing one phase, divided by the total length of line traversing a two-dimensional section, is in direct proportion to the amount of that phase present in the total sample (by volume). This is provided that the shape of the cells in the phase has no preferred orientation and that the sample is representative of the whole. This ratio is proportional not only to volume (usually given in per cent) but also to the area of the phase divided by the total area of the thin section.

A large single crystal can be treated as a phase or as a separate mineral and its total volume calculated, except that a random section is not likely to cut a single crystal in a representative manner. Therefore, the area of a crystal exposed in a thin section can be calculated by the line method, and where consecutive thin sections are close together, the area multiplied by the thickness gives a very close approximation of the volume. This is true even with sloping boundaries, if the area is taken in the center of the segment. In this case, the grid was chosen with a spacing of $0.5 \mathrm{~cm}$ and therefore the area in square centimeters is one-half the length of line in centimeters. The volumes of each individual segment are added for the total volume of the crystal.

The thickness ( $t$ column in Tables I and II) for any section was found by taking half the distance between the section chosen and the section above, and then adding that value to half the distance to the section below. Column $V$ in Tables I and II presents the results of these calculations; column $L$ is the total length of line in the various parts of the two crystals, $\mathrm{A}$ and $\mathrm{B}$.

For a three-dimensional grid, the ratio of the length of line in the crystal to the total length of line in the sample block also gives the volume of the crystal. The ratio of the area of the crystal in each section to the total area of the crystal segment is proportional to the total volume of the segment of $t$ thickness. Therefore, if the segment thicknesses were constant, all areas could be added to give the percentage of the crystal to the whole. Because they were not of constant thickness, the volume of each segment had to be calculated separately.

Smith and Guttman (1953) have shown by a study of geometric probabilities that in a two-dimensional structure the ratio of the length of perimeter to the area enclosed is a simple direct function of the average number of intercepts per unit length of an intersecting straight line (or grid) randomly applied to the structure. This ratio is $p / A=\pi \mathcal{N} / 2 L$, where $p$ is the perimeter of the cells (in the case illustrated here), $A$ is the area of the cells, $\mathcal{N}$ is the total number of intercepts with $p$, and $L$ is the total length of the straight line in the cells being measured.

They have also shown that the average number of intercepts per unit length of a random line (or grid) drawn through a three-dimensional structure is exactly half the true ratio of 
surface to volume: $S / V=2 \mathcal{N} / L, S$ is surface area and $V$ is the volume of the cell or cells, and $\mathcal{N}$ and $L$ are as defined above. Therefore, with this ratio and the volume, the surface area can be calculated.

The use of these two relationships makes it possible to obtain the volume and surface area of both crystals A and B (Tables I and II). The grid with a spacing of $0.5 \mathrm{~cm}$ simplified calculations. To assure that this spacing was not too large, the areas of the grains on many sections were also measured by planimeter which checked within 2 per cent in most cases. The surface areas, $S$, given in Tables I and II do not include the top and bottom surfaces of the segment which are not part of the crystal surface.

Table III. Perimeters of Grains by Intercept

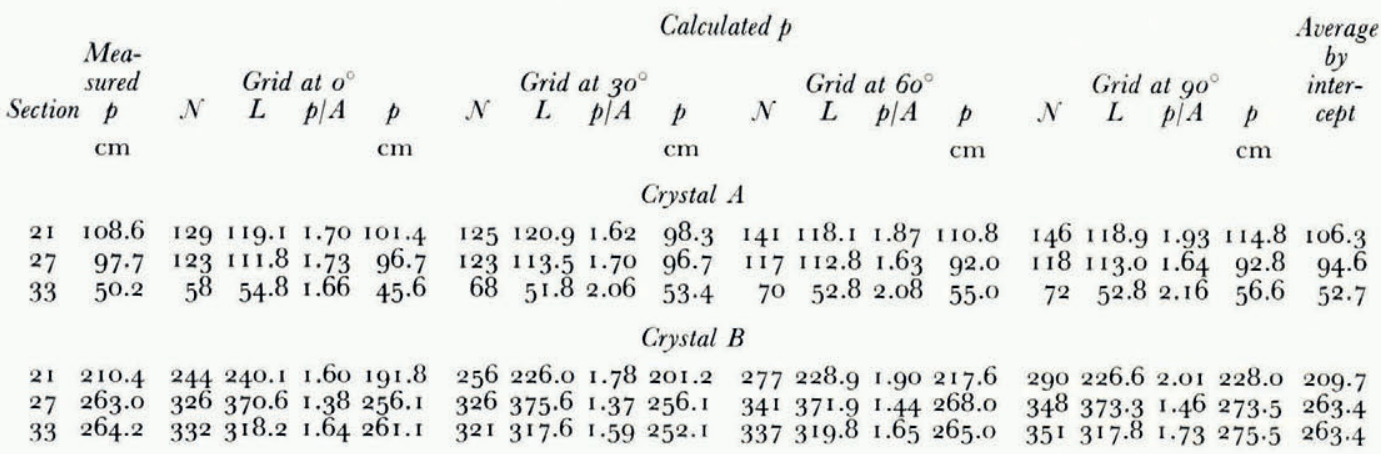

Table III gives the measured value of $p$ by map measurer and the calculated value of $p$, using intercepts, in four orientations of the grid on three sections. The fact that the number of intercepts was somewhat higher for some orientations of the grid shows that the grains were not completely at random in their shape (the long dimension of the grains tended to have a preferred directionality). The lines of the grid were first parallel to the bottom edge (called $0^{\circ}$ ), then the measurements and counts on the same grains were made at $30^{\circ}, 60^{\circ}$ and $90^{\circ}$ rotation. It will be noted that the values of $L$ (and therefore the area) remain nearly constant regardless of the orientation of the grid, but that the values of $\mathcal{N}$ change.

The value of $p / A$ and $S / V$ obtained by averaging the $L$ and $\mathcal{N}$ values in these different directions are quite close to the measured value and therefore are considered more accurate. Because the length, $L$, did not change appreciably with grid orientation, this was usually measured only once, but most of the values for $\mathcal{N}$ are averages of two or more grid orientations.

The photographs of section 4 (Figs. I and 2) and section I7 (Fig. 3) visually show some elongation of the grains along parallel lines dipping to the right and making about a $25^{\circ}$ angle to the bottom edge. These lines are parallel to the foliation in the ice and the number of intercepts was greater, generally, when the grid was placed perpendicular to this foliation direction than when parallel to it.

Where the crystal is not complete along the sample edge due to the saw cut, the length of line, $L$, was measured to this straight line which is obviously not the crystal boundary, but the intercepts on this edge were not counted because the errors would have been compounded. For the same reason, only the exposed part of the actual boundary was measured with the map measurer. A discussion concerning the counting of intercepts on incomplete grains will be given in the appendix to the more complete report (Rigsby, in press).

Smith and Guttman (1953) have stated that in using the relationships, $p / A=\pi \mathcal{N} / 2 L$ and $S / V=2 \mathcal{N} / L$, "It is not necessary to utilize a well-ruled grid of parallel lines, but any array of lines repeatedly applied to the structure in a random fashion is satisfactory provided 
that a sufficient number of intersections is counted. If the structure itself is random, a single line (not necessarily straight) of sufficient length is adequate."

It must be remembered, however, that these relationships presented by Smith and Guttman are generally applied to various phases in a representative sample and certain considerations must be made which cannot be called random when applied to measuring parameters of a single crystal. For example, the grid can be applied in a random fashion on a two-dimensional surface if the grain shape can be considered isotropic, but the grid must cover all the parts of the crystal in the sample in order to obtain the volume and area-to-volume ratio for only one particular crystal. Also, a well-ruled grid of parallel lines with a constant spacing must be used for calculations of the area cut by the thin section. The distance between sections becomes important as this affects the volume found in the segment. Therefore, special applications of these formulae are used in this paper and the intercepts of the ruled grid are used as a method to find the surface area of the crystals which would be difficult to measure in any other way.

The use of a grid of $0.5 \mathrm{~cm}$ spacing allows some simplification of the calculations. The following relations hold:

$$
\begin{gathered}
A=L / 2, \\
p / A=\pi \mathcal{N} / 2 L, \\
p=\pi \mathcal{N} A / 2 L=\pi \mathcal{N} L / 4 L=\pi \mathcal{N} / 4, \\
V=A t, \\
S / V=2 \mathcal{N} / L, \\
S=2 \mathcal{N} V / L=2 \mathcal{N} A t / L=2 \mathcal{N} L t / 2 L=\mathcal{N} t,
\end{gathered}
$$

where $L$ is the total length of the grid lines within the crystal boundaries, $\mathcal{N}$ is the total number of intercepts of the grid lines with crystal boundaries (if a line is only tangent to the boundary there is only one intercept), $A$ is the area of the surface cut by the thin section, $S$ is the area of the crystal surface, $p$ is the perimeter of surface $A$ in the thin section and $V$ is the volume of the crystal. Of course, these simplified formulae for $A, p$ and $S$ apply only for the special case where the spacing of the grid lines is one-half the units being used.

The volume ( $V$ column) is calculated by taking the area represented in each thin section and multiplying by the thickness of the increment. Volume differences due to any sloping boundary surfaces above and below the center are expected to be averaged by taking the area in the center of the increment. The total volume of crystal A, adding all segments together, is $776.5 \mathrm{~cm}^{3}$, and the volume of crystal B in the sample obtained by adding segments is $2364.7 \mathrm{~cm}^{3}$.

$S / V$ for crystals $\mathrm{A}$ and $\mathrm{B}$, as found for each section, is given in Tables I and II. The surface area of each increment was calculated and is given in the $S$ column. The total area of the natural surface of the crystal in the sample is simply the sum of the increments in the $S$ column. This value is the most accurate way of finding the surface area because each increment is weighted correctly by the volume which is a function of the increment thickness.

It might be argued that the $S$ to $V$ ratio for only a part of a crystal has little meaning as it represents the crystal as a whole, and that the true value of this sample ratio is affected by size, assuming some sort of constant shape. An attempt to show that the ratio on only a part of the crystal is approximately the same as that on the whole crystal is made in Table IV. $S / V$ is calculated for various parts of each crystal and comparisons can be made. It will be noted that the ratios for crystal $\mathrm{B}$ are quite close regardless of which part of the crystal they are calculated for, except in the first ten sections the ratio is higher where the crystal is rapidly expanding in size. Perhaps there is not enough of the crystal in these first sections to give a good value. The same thing is noted for crystal A except that the value of the ratio is low for the first ten sections and high for the last ten sections, and the value approaches the one for the whole crystal as more sections are included. Apparently the top part of this crystal is simpler in its shape, giving lower values for $S / V$. In general, one would not expect this much change 
in the value of the ratio between two sides of a crystal. Note also that the value of the ratio is quite close to the total figure for only the center ten sections of each crystal ( 1.982 for crystal A as a whole and 2.020 for the center ten sections; 2.157 for the total sample of crystal B and 2.06I for sections $2 \mathrm{I}-30$ ).

Table IV. $S / V$ and $S^{3 / 2} / V$ Ratios for Various Parts of the Crystals

\begin{tabular}{|c|c|c|c|c|c|c|}
\hline Sections & $\mathcal{N}$ & $L$ & $V$ & $S$ & $S / V$ & $S^{3 / 2} / V$ \\
\hline \multicolumn{7}{|c|}{ Crystal $A$} \\
\hline $\mathrm{I}-\mathrm{I} 5$ & 705 & $964 \cdot$ I & I93.52 & 283.10 & I. 463 & $24.6 \mathrm{I} 4$ \\
\hline$I-20$ & I 283 & I 549.5 & $3^{18} \cdot 3^{2}$ & $53^{1.1} 5$ & I. 669 & $3^{8} \cdot 4^{6}$ \\
\hline $1-25$ & I 977 & 225 I.I & $505 \cdot 45$ & 895.60 & 1. 772 & 53.03 \\
\hline$I-30$ & $25^{8} 3$ & 2821.7 & 629.12 & $115^{8.9} 1$ & 1. $84^{2}$ & 62.71 \\
\hline $\mathrm{I}-35$ & 2993 & 3 I 39.2 & 703.93 & I 337.97 & I 907 & 69.53 \\
\hline $1-40$ & 3290 & $33^{6} 7 \cdot 4$ & $75^{8.8 I}$ & I 480.6 I & I. 954 & 75.08 \\
\hline$I-48$ & 3374 & 3437.0 & 776.53 & I 539.16 & 1. 982 & $77 \cdot 76$ \\
\hline $39-4^{8}$ & 219 & I $4^{1} \cdot 4$ & 33.93 & $105.9 \mathrm{I}$ & $3.13 \mathrm{I}$ & 32.123 \\
\hline $34-4^{8}$ & $5^{13}$ & 393.8 & $93 \cdot 75$ & 245.57 & $2.6 \mathrm{Ig}$ & $4^{1.048}$ \\
\hline $29-4^{8}$ & 1022 & 839.7 & 193.14 & $474 \cdot 36$ & $2.45^{6}$ & $53 \cdot 49^{2}$ \\
\hline $24-48$ & 1 616 & I $46 \mathrm{I} .5$ & $33^{1} \cdot 47$ & $774 \cdot 3^{6}$ & $2.33^{6}$ & 65.009 \\
\hline $19-4^{8}$ & 2326 & 2097.5 & 505.83 & I 1 I $14.3^{8}$ & 2.203 & 73.544 \\
\hline $2 \mathrm{I}-30$ & 1300 & 1272.2 & 310.80 & $627 \cdot 76$ & 2.020 & 50.607 \\
\hline \multicolumn{7}{|c|}{ Crystal B } \\
\hline$I-15$ & $85^{1}$ & $65^{2.6}$ & ${ }^{1} 36.45$ & $35^{2.70}$ & $2.5^{8} 5$ & $4^{8.544}$ \\
\hline $1-20$ & I 767 & I 669.0 & $354.4^{\circ}$ & 746.21 & 2.106 & $57.5^{17}$ \\
\hline$I-25$ & 3273 & 3029.9 & 713.64 & I 541.27 & 2.160 & 84.786 \\
\hline $1-30$ & 5074 & 4901.9 & 1117.03 & 2318.30 & 2.075 & $99 \cdot 929$ \\
\hline $1-35$ & 6708 & 6464.2 & I 484.28 & 3085.82 & 2.079 & 115.489 \\
\hline$I-40$ & 8376 & 7919.6 & I 830.56 & 388 r.29 & 2120 & 132.082 \\
\hline $\mathrm{I}-4^{8}$ & 10 597 & 98 I 5.0 & $2364 \cdot 72$ & 5100.02 & 2.157 & 153.670 \\
\hline $44^{-48}$ & I 247 & I 141.2 & $33^{8.08}$ & 711.57 & 2.105 & 56.144 \\
\hline $39^{-48}$ & 2933 & 2544.0 & $679 \cdot 34$ & I 539.75 & 2.267 & $88.93^{8}$ \\
\hline $34-48$ & $44^{6} \mathrm{I}$ & 3889.0 & 998.0 I & 2266.13 & $2.27 \mathrm{I}$ & I08.093 \\
\hline $29-48$ & 6289 & 5724.9 & I 412.45 & 3093.23 & $2.19^{\circ}$ & 121.800 \\
\hline $24-4^{8}$ & 7978 & $73^{80.7}$ & I 780.74 & 3844.68 & 2.1 59 & ${ }^{1} 33.872$ \\
\hline $19-4^{8}$ & 9212 & $8595 \cdot 4$ & $2111.3^{2}$ & $45^{1} 5 \cdot 9^{1}$ & 2.139 & I 43.735 \\
\hline $2 \mathrm{I}-30$ & 3308 & 3214.9 & 762.63 & I 572.09 & $2.06 \mathrm{I}$ & 81.734 \\
\hline
\end{tabular}

\section{Crystal Irregularity}

Introduced here is another parameter for solids not previously seen in the literature, a dimensionless ratio called an irregularity factor or jaggedness ratio. A similar ratio has been used in two dimensions by Pounder and Little (1959) in trying to distinguish between glacier ice and sea ice. They used the ratio of the perimeter squared to the area on photographs as a numerical value for their "jaggedness ratio", because this removes the size factor of the grain from the value. For example, the most regular or least jagged would be a circle, and the value of $p^{2} / A$ for a circle of any size is $4 \pi$ or $12.566 \cdots$; any other shape will give a larger number than $4 \pi$. This led to the reasoning that if one raised the surface area of a solid to the power of $3 / 2$ and divided by the volume that again a dimensionless ratio is obtained and a numerical figure could then indicate an irregularity or jaggedness ratio. Using a sphere as the least jagged, the numerical value of $S^{3 / 2} / V$ of any sphere is six times the square root of $\pi$ or ro.6347 $\cdots$, and any other shape will give a larger number. For example, the value of $S^{3 / 2} / V$ for any size cube is $14.697 \cdots$ and for a tetrahedron the value is $19.344^{\cdots} \cdots$. 
To illustrate the irregularity of crystal A in the section drawings (Figs. 7-14), the jaggedness value is 77.76 , and for crystal B the value is 153.67 for the part of the crystal in the sample. The calculations are given below:

$$
\begin{aligned}
& \frac{(\mathrm{I} 539 . \mathrm{I} 6)^{3 / 2}}{776.53}=77.76 \\
& \frac{(5 \mathrm{ro0.02})^{3 / 2}}{23^{64.72}}=\text { I } 53.67 .
\end{aligned}
$$

Crystal B does appear to be more irregular because of the many branches, some of which have a small size, and therefore it appears that the numerical value is at least this large. The true value is probably somewhat larger than $\mathrm{I}_{53.67}$, if the trend indicated in the last column of Table IV is correct as larger and larger parts of the crystals are taken.

Table IV gives the various values of this irregularity or jaggedness ratio for the same parts of crystals $\mathrm{A}$ and $\mathrm{B}$ which were used for the simple $S / V$ ratio. It is obvious that the ratio does become larger as more and more of the crystal is included. This indicates that the complete crystal is necessary for the numerical value to have much meaning. Although this ratio is dimensionless and does not change with crystal size, the shape obviously is not expressed completely by only a part of the crystal. Therefore, $S^{3 / 2} / V$ for crystal B, as with any incomplete crystal, is not absolutely correct, but the appearance is certainly that it is much more irregular than crystal A. This subject is discussed at greater length in the appendix to the paper by Rigsby (in press).

As has already been shown, the $S / V$ ratio tends to remain constant for any proportion of the crystal. If this is true in general, then it is impossible for $S^{3 / 2} / V$ to remain constant for varying parts of the crystal.

The over-all usefulness of this irregularity ratio may be limited to complete crystals, but it appears to the writer that the concept may be a useful one.

\section{Conclusions}

The most striking result of this study is the ability to demonstrate complexities in shapes of ice crystals in a block of glacier ice. It is probable that most ice near the surface in the active terminus area of temperate glaciers will have similar complex crystal shapes, interlocking in complicated ways and of much more extended dimensions than usually thought. Although Bader (I95I) showed that the stagnant ice in Malaspina Glacier, Alaska, had large interlocking crystals, the idea has persisted that in more active ice the crystals would be geometrically more simple and not so extensive. This may be partly because it was reasoned that movement would not allow such extensive crystals to develop, and partly because the crystals appear in two dimensions to be relatively simple and roughly equidimensional. Bader's work on Malaspina Glacier did not show as much complexity as demonstrated here.

This study also throws some doubt on many of the fabric diagrams obtained in active temperate glacier ice, including those of this writer, because of the likelihood that many of the axes plotted in one maximum really represent a single crystal. When one considers that there can be at least a $10^{\circ}$ spread of the orientation direction of the axis as measured in different parts of a crystal plus the errors in measuring on the universal stage, it is easy to understand why each separate cell in a thin section would usually be considered a separate crystal. In fabric work, the writer, along with many others, considered each cell in a thin section as a separate crystal, unless two or more cells had the same extinction angle and were near each other. It did not seem possible at that time that cells $30 \mathrm{~cm}$ or more apart in ice of this so-called "grain-size" could still be part of the same crystal. It is not known at this time if the finer-grained ice from polar glaciers or from the highly stressed zones in temperate glaciers have this same complexity in shape. 


\section{AcKnowledgements}

Appreciation is hereby expressed for the support (both financial and in equipment and laboratory space) given by the Cold Regions Research and Engineering Laboratory, Hanover, New Hampshire, and to the Arctic Institute of North America, which obtained and administered this support. The author wishes also to thank Gerald R. McEnroe, who was assigned by CRREL to help with much of the routine work of measuring the orientation of the optic axes on the universal stage in many of the sections, which was necessary for identification of individual crystals from section to section. Appreciation is also expressed to E. R. LaChapelle, University of Washington, for help during sample collection.

MS. received 6 June 1967

\section{REFERENCES}

Bader, H. I951. Introduction to ice petrofabrics. Fournal of Geology, Vol. 59, No. 6, p. 519-36.

Pounder, E. R., and Little, E. M. 1959. Some physical properties of sea ice. I. Canadian Journal of Physics, Vol. 37 , No. 4, p. 443-73.

Rigsby, G. P. 1951. Crystal fabric studies on Emmons Glacier, Mount Rainier, Washington. Journal of Geology, Vol. 59, No. 6, p. $59^{0}-98$.

Rigsby, G. P. I955. Study of ice fabrics, Thule area, Greenland. U.S. Snow, Ice and Permafrost Research Establishment. Report 26.

Rigsby, G. P. 1960. Crystal orientation in glacier and in experimentally deformed ice. Fournal of Glaciology. Vol. 3, No. 27, p. 589-6o6.

Rigsby, G. P. In press. The shape of crystals in glacier ice. U.S. Cold Regions Research and Engineering Laboratory. Research Report 224.

Smith, C. S., and Guttman, L. 1953. Measurement of internal boundaries in three-dimensional structures by random sectioning. Fournal of Metals, Vol. 5, No. 1, p. 81-87. 